\title{
An approach towards chiral 5-hydroxyalkyl butan-4-olides: total synthesis of (-)-muricatacin and related natural products
}

\author{
M. Chandrasekhar, Kusum L. Chandra, and Vinod K. Singh* \\ Department of Chemistry, Indian Institute of Technology \\ Kanpur, India - 208016 \\ E-mail:vinodks@iitk.ac.in
}

Dedicated with respect to Professor S. V. Kessar on his $70^{\text {th }}$ birthday

(received 21 Apr 02; accepted 13 Jun 02; published on the web 21 Jun 02)

\begin{abstract}
A general approach towards synthesis of 5-hydroxyalkylbutan-4-olides from D-mannitol has been described. The approach has been used successfully for total synthesis of (-)-muricatacin, an anti-tumour natural product. Other related natural and unnatural compounds were also synthesized.
\end{abstract}

Keywords: D-Mannitol, (-)-muricatacin, 5-hydroxyalkyl butan-4-olides

\section{Introduction}

Chiral hydroxylactones occupy an important position as bio-active molecules and useful synthetic intermediates in total synthesis. One such group of hydroxylactones is 5hydroxyalkylbutan-4-olides $\mathbf{1}$. These are found widely in nature and show diverse biological properties. Some of these compounds are known to have insect antifeedant activity ${ }^{1}$ and are cytotoxic to human tumor cells. ${ }^{2}$ The short chain homologues are important flavor constituents in wine, sherry, and tobacco smoke. ${ }^{3}$ These are also found in microbial metabolite cultures of Erwinia quernica ${ }^{4}$ and Streptomyces griseus. ${ }^{5}$ Many of these butanolides are often used as synthons in the synthesis of complex and biologically important natural products. ${ }^{6}$ These have been used as precursors to HIV-1 protease inhibitors. ${ }^{7}$ One such molecule that has attracted much attention since its isolation was (-)-muricatacin 1d. It was isolated from the seeds of Anona muricata L. (annonaceae), ${ }^{8}$ commonly known as sour group or guanabana, and is grown commercially as a fruit crop throughout the tropical regions of the world. This plant, as well as others in the family of annonaceae, are a source of many annonaceous acetogenins that are known to have anti-tumor properties. ${ }^{2}$ Both the enantiomers of $\mathbf{1 d}$ are found in nature. The isolated material is a mixture of the two, the (-)-(R,R)-1d being predominant (ee of ca. $25 \%$ based on optical rotation). It is shown to be cytotoxic towards human tumor cells. Biological 
studies revealed that the length of the side chain is very crucial. Decreasing the length of the alkyl side chain led to decreased activity and increasing the chain length did not show any increase in the activity. Both (+)- and (-)-muricatacin (threo) have the same activity. The biological activity of muricatacin and other related compounds prompted many syntheses of this type of molecule. ${ }^{9-11}$ Most of the known syntheses are target oriented. In this paper we describe a general approach towards hydroxy lactones from D-mannitol. ${ }^{12}$ We have also synthesized (-)muricatacin and related natural products.

\section{Results and Discussion}

While working on total synthesis of (-)-boronolide ${ }^{13}$ and hexadecanolide, a pheromone ${ }^{14}$ we realized that 5-hydroxyalkylbutan-4-olides 1 type natural products can also easily be synthesized from D-mannitol. The retrosynthetic analysis for our approach is shown in Scheme 1. The $\gamma$ lactone unit can be constructed from the corresponding hydroxy acid, which can come from the acetonide 2. The appropriate alkyl group can be added on the aldehyde of $\mathbf{3}$ (Scheme 1).

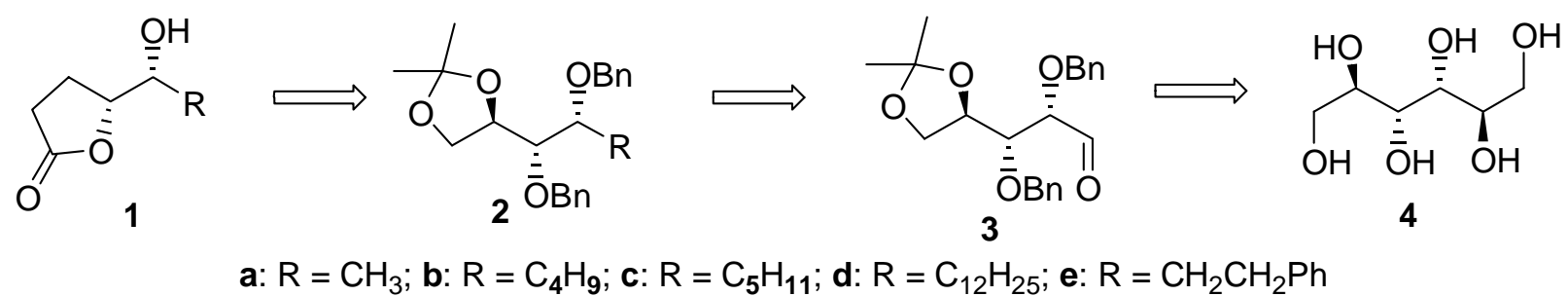

Scheme 1. Retrosynthetic analysis.

The synthesis commences with diacetonide benzyl ether 5, which was subjected to selective hydrolysis using acetyl chloride in $\mathrm{MeOH}$ at $0{ }^{\circ} \mathrm{C}$ to give a diol 6 in $88 \%$ yield. ${ }^{15}$ The diol 6 was subjected to oxidative cleavage using LTA in $\mathrm{CH}_{2} \mathrm{Cl}_{2}$ and the crude aldehyde was reduced with $\mathrm{NaBH}_{4}$ to provide the alcohol 7. The alcohol was then tosylated, and the crude tosylate was reduced with $\mathrm{NaBH}_{4}$ in DMSO to give 8, whose acetonide group was cleaved using trifluoroacetic acid in THF-water mixture (4:1). The diol 9, thus obtained, was cleaved to aldehyde by using LTA. The aldehyde, without any purification, was subjected to Wittig olefination reaction with (benzyloxycarbonylmethylene)triphenylphosphorane to obtain $\alpha, \beta$ unsaturated ester 10, which was converted into the target compound 1a by hydrogenation over $\mathrm{Pd} / \mathrm{C}$ followed by treatment of the resulting crude hydroxy acid with $p$-TsOH (Scheme 2). 


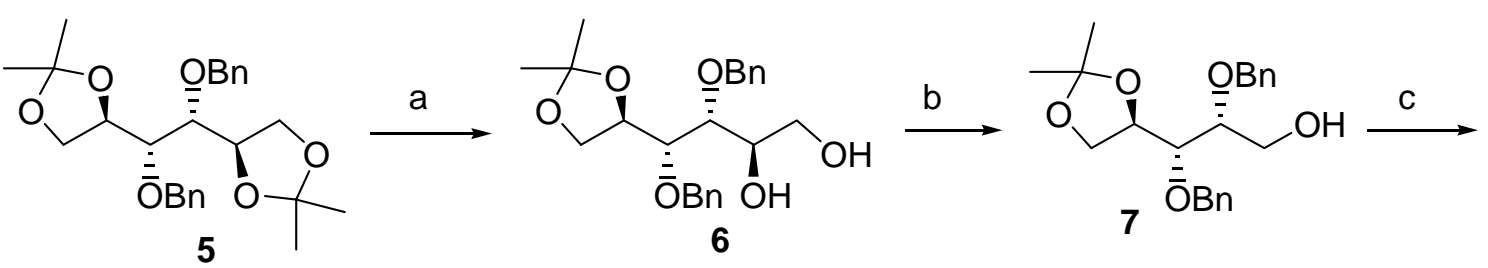<smiles>C[C@@H](Cc1ccccc1)[C@H](C)OCc1ccccc1</smiles>

a: $\mathrm{AcCl}$ (5 equivalents), $\mathrm{MeOH}, 0{ }^{\circ} \mathrm{C}, 5 \mathrm{~min}$ ( $88 \%$ yield). b: (i) $\mathrm{Pb}(\mathrm{OAc})_{4}, \mathrm{CH}_{2} \mathrm{Cl}_{2}$, rt, 3 h. (ii) $\mathrm{NaBH}_{4}, \mathrm{EtOH}, 0{ }^{\circ} \mathrm{C}, 2 \mathrm{~h}$ (96 \% yield). c: (i) TsCl, $\mathrm{Et}_{3} \mathrm{~N}, \mathrm{CH}_{2} \mathrm{Cl}_{2}, 14$ h; (ii) $\mathrm{NaBH}_{4}, \mathrm{DMSO}, 160$ ${ }^{\circ} \mathrm{C}, 7$ min (73 \% yield). d: TFA, THF- $\mathrm{H}_{2} \mathrm{O}$ (4:1), $65{ }^{\circ} \mathrm{C}, 6 \mathrm{~h}$ (86 \% yield). e: (i) $\mathrm{Pb}(\mathrm{OAc})_{4}$, $\mathrm{CH}_{2} \mathrm{CL}_{2}$, rt, 3 h; (ii) $\mathrm{BnO}_{2} \mathrm{CCH}_{2} \mathrm{P}^{+} \mathrm{PhBr}^{-}, n$-BuLi, THF, $0{ }^{\circ} \mathrm{C}$-rt, $12 \mathrm{~h}$ (74 \% yield). f: (i) $\mathrm{H}_{2}, 10 \%$ $\mathrm{Pd} / \mathrm{C}$, EtOH, rt, $12 \mathrm{~h}$; (ii) $p$ - TSA, toluene, $70{ }^{\circ} \mathrm{C}, 1 \mathrm{~h}(95 \%$ yield $)$

Scheme 2. Synthesis of 1a.

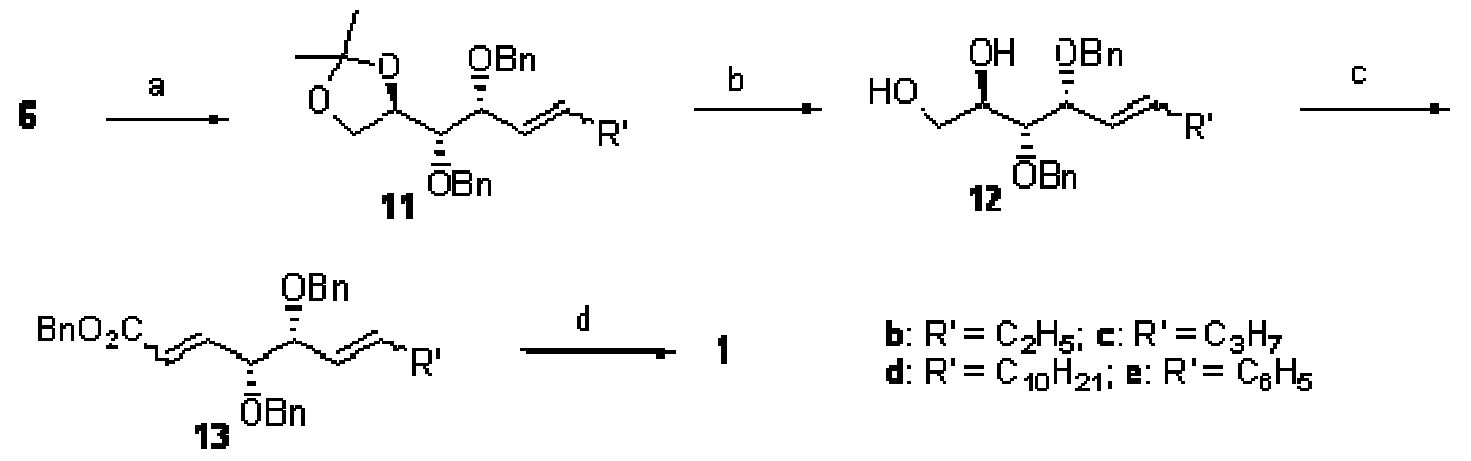

a: (i) $\mathrm{Pb}(\mathrm{OAc})_{4}, \mathrm{CH}_{2} \mathrm{Cl}_{2}$, rt, $3 \mathrm{~h}$; (ii) $\mathrm{R}^{\prime} \mathrm{CH}_{2} \mathrm{Ph}_{3} \mathrm{Br}^{-}, n$-BuLi, THF, $0{ }^{\circ} \mathrm{C}-r t, 12 \mathrm{~h}$ (65-75 \% yield). b: TFA, THF- $\mathrm{H}_{2} \mathrm{O}$ (4:1), $65{ }^{\circ} \mathrm{C}, 6 \mathrm{~h}\left(85-95 \%\right.$ yield). c: (i) $\mathrm{Pb}(\mathrm{OAc})_{4}, \mathrm{CH}_{2} \mathrm{Cl}_{2}, \mathrm{rt}, 3 \mathrm{~h}$; (ii) $\mathrm{BnO}_{2} \mathrm{CCH}_{2} \mathrm{P}^{+} \mathrm{Ph}_{3} \mathrm{Br}^{-}, n$-BuLi, THF, $0{ }^{\circ} \mathrm{C}-\mathrm{rt}, 12 \mathrm{~h}$ (70-80 \% yield). d: (i) $\mathrm{H}_{2}, 10 \% \mathrm{Pd} / \mathrm{C}, \mathrm{EtOH}, \mathrm{rt}$, $12 \mathrm{~h}$; (ii) $p$-TSA, toluene, $70{ }^{\circ} \mathrm{C}, 1 \mathrm{~h}(92-95 \%$ yield $)$.

Scheme 3. Synthesis of 1b-e.

We extended the above approach to compounds with different alkyl groups in the side chain. For alkyl groups other than methyl, the scheme was modified. The aldehyde, obtained from the diol 6, was treated with ylides, prepared from phosphonium salts with different alkyl groups to provide olefins 11. The acetonide group of 11 was cleaved, as described earlier. The diol 12, thus obtained, was converted into the olefinic compound $\mathbf{1 3}$ using the aforementioned 
Wittig chemistry. Conversion of $\mathbf{1 3}$ into target compounds such as $\mathbf{1 b}, \mathbf{1 c}, \mathbf{1 d}$, and $\mathbf{1 e}$ was carried out as described for 1a. In this way, we were able to synthesize several hydroxyalkyl $\gamma$ lactones in $\sim 45 \%$ overall yield (Scheme 3 ).

In order to show some more versatility in our approach, we set out to synthesise some analogues having extra hydroxy groups. This was accomplished from the known diol 14, ${ }^{13}$ which was subjected to oxidative cleavage with LTA, and the aldehyde obtained was then allowed to react with the ylide prepared from (ethoxycarbonylmethylene)triphenylphosphorane to provide $\alpha, \beta$-unsaturated ester 15 as a mixture of cis and trans isomers (ratio 70:30). The mixture, on treatment with $\mathrm{CuCl}_{2} \cdot 2 \mathrm{H}_{2} \mathrm{O}^{16}$ gave the lactone after cleaving the acetonide group. Only the cis isomer lactonized, and the trans isomer remained unreacted. The unsaturated lactone 16 was hydrogenated to provide a saturated lactone 17 which could be an important precursor in synthesis (Scheme 4).
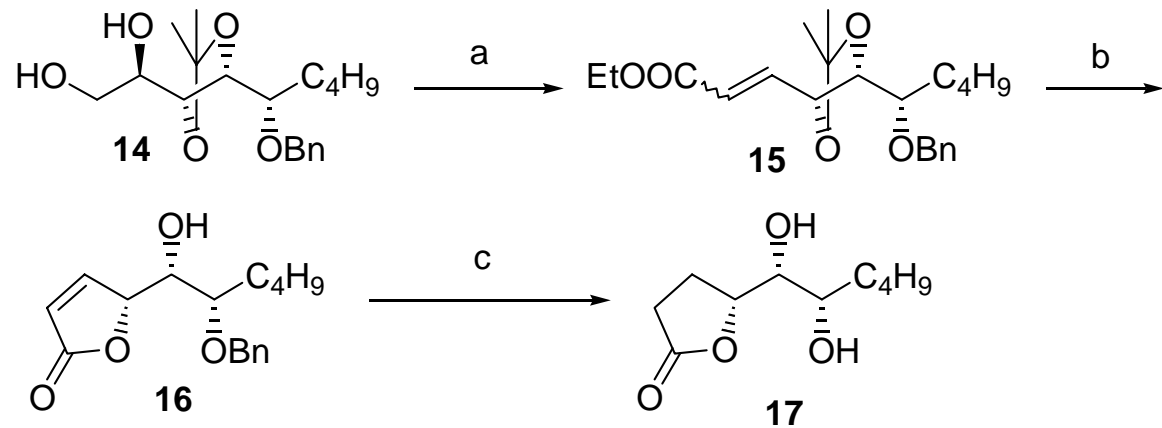

a. (i) $\mathrm{Pb}(\mathrm{OAc})_{4}, \mathrm{CH}_{2} \mathrm{Cl}_{2}$, rt, $3 \mathrm{~h}$; (ii) $\mathrm{EtO}_{2} \mathrm{CCH}=\mathrm{PPh}_{3}, \mathrm{MeOH}$, rt, $12 \mathrm{~h}$ (75 \% yield);

b. $\mathrm{CuCl}_{2} .2 \mathrm{H}_{2} \mathrm{O}, \mathrm{MeCN}, \mathrm{rt}, 12 \mathrm{~h}$ (65\% yield); c. $\mathrm{H}_{2}, 10 \% \mathrm{Pd} / \mathrm{C}, \mathrm{EtOH}, \mathrm{rt}, 12 \mathrm{~h}$.

Scheme 4. Synthesis of 17.

\section{Conclusions}

We have developed a simple and flexible strategy for the synthesis of hydroxyalkylbutan-4olides from D-mannitol. Using the above strategy, a total synthesis of (-)-muricatacin and related compounds was accomplished.

\section{Experimental Section}

\section{General procedure for oxidative cleavage of diols $\left(6,9,12\right.$, or 14) using $\mathrm{Pb}(\mathrm{OAc})_{4}$}

To a solution of a diol in dry $\mathrm{CH}_{2} \mathrm{Cl}_{2}(5 \mathrm{ml} / \mathrm{mmol})$, LTA $\left(1.1\right.$ eq.) was added at $0{ }^{\circ} \mathrm{C}$ and the reaction was allowed to proceed with gradual warming to rt. After all the diol was consumed (by tlc, usually $4 \mathrm{~h}$ ), the reaction mixture was quenched by an addition of saturated aqueous $\mathrm{NaHCO}_{3}$ solution. The solids were removed by filtration through celite pad. The aqueous layer was 
extracted with $\mathrm{CH}_{2} \mathrm{Cl}_{2}$ and the combined organic layers were washed with water and brine. The organic layer was then dried over anhydrous $\mathrm{Na}_{2} \mathrm{SO}_{4}$ and concentrated in vacuo to give an aldehyde in quantitative yield, which was used as such in the next step.

\section{General procedure for the synthesis of olefins (11)}

To a suspension of a Wittig salt (1.3 eq with respect to aldehyde) in anhydrous THF (5 $\mathrm{mL} / \mathrm{mmol}$ ) at $0{ }^{\circ} \mathrm{C}$, $\mathrm{n}$-BuLi (1.3 eq., $1.43 \mathrm{M}$ in hexanes) was added under $\mathrm{N}_{2}$ atmosphere and was stirred for $30 \mathrm{~min}$ at the same temperature. To the resulting orange red solution, the crude aldehyde (obtained by an oxidative cleavage of the diol 6) in anhydrous THF $(1 \mathrm{ml} / \mathrm{mmol}$ ) was added slowly over a period of $10 \mathrm{~min}$. The reaction mixture was stirred for $6 \mathrm{~h}$ with gradual warming to rt. All the solids were removed by filtration and the organic layer was concentrated and chromatographed over silica gel to give the olefins as a mixture of cis-trans isomers.

\section{General procedure for cleavage of acetonide (8 or 11) with TFA}

To a solution of acetonide (8 or 11) in THF and water (4:1) was treated with trifluoroacetic acid (1.5 equivalent) at $65^{\circ} \mathrm{C}$. After all the starting material was consumed (by tlc, usually $6 \mathrm{~h}$ ), THF was removed in vacuo and the aqueous layer was extracted with EtOAc. The combined organic layers were washed with saturated aqueous $\mathrm{NaHCO}_{3}$ solution, water, and brine. The organic layer was finally dried over anhydrous $\mathrm{Na}_{2} \mathrm{SO}_{4}$, concentrated in vacuo and chromatographed over silica gel to give the diol 9 or 12.

\section{General procedure for synthesis of $\alpha, \beta$-unsaturated esters (10 or 13)}

To a suspension of a Wittig salt (1.3 eq. with respect to a diol, obtained by treatment of benzyl bromoacetate with triphenylphosphine) in anhydrous THF $(5 \mathrm{~mL} / \mathrm{mmol})$ at $0{ }^{\circ} \mathrm{C}$ was added $\mathrm{n}$ $\mathrm{BuLi}$ (1.3 eq. with respect to diol) under $\mathrm{N}_{2}$ atmosphere and stirred for $30 \mathrm{~min}$. To this clear solution was added the crude aldehyde (obtained by oxidative cleavage of the corresponding diol) in anhydrous THF ( $1 \mathrm{ml} / \mathrm{mmol})$ and stirred over night with gradual warming to rt. THF was removed in vacuo and the residue was chromatographed over silica gel to give the $\alpha, \beta$ unsaturated esters. The $\alpha, \beta$-unsaturated ester was subjected to lactonization without purification and characterization.

\section{General procedure for the synthesis of lactones (1)}

The $\alpha, \beta$-unsaturated ester (10 or 13) was dissolved in $\mathrm{EtOH}(3 \mathrm{~mL} / \mathrm{mmol})$ and $50-60 \mathrm{mg}$ of $10 \% \mathrm{Pd}$ on activated charcoal was added to it. The flask was evacuated and purged with $\mathrm{H}_{2}$ gas and the reaction was allowed to proceed for $12 \mathrm{~h}$ at $\mathrm{rt}$ under a balloon filled with $\mathrm{H}_{2}$ gas. The reaction mixture was filtered through celite, washed with little $\mathrm{EtOH}$, and concentrated in vacuo. The residue was taken in benzene $(5 \mathrm{ml} / \mathrm{mmol})$ and $5-10 \mathrm{mg}$ of $p$-TSA was added and refluxed for $1 \mathrm{~h}$. It was diluted with EtOAc and washed successively with water and brine. Finally the organic layer was dried over $\mathrm{Na}_{2} \mathrm{SO}_{4}$, concentrated and chromatographed over silica gel to give the lactone. 
3,4-Di-O-benzyloxy-5,6-O-isopropylidene-D-mannitol (6). A solution of mannitol derivative 5 $(15 \mathrm{~g}, 34 \mathrm{mmol})$ in dry $\mathrm{MeOH}(135 \mathrm{~mL})$ was treated by a drop wise addition of $\mathrm{AcCl}(12.1 \mathrm{~mL}$, $170 \mathrm{mmol}$ ) at $0{ }^{\circ} \mathrm{C}$ and the reaction mixture was stirred for $5 \mathrm{~min}$. It was quenched by an addition of $\mathrm{KOH}$ solution (19.1 g, $340 \mathrm{mmol}$ in 1:1 MeOH-water, $60 \mathrm{~mL}$ ). Most of the $\mathrm{MeOH}$ was removed in vacuo, the solid residue was taken in water and extracted with EtOAc. The combined organic layers were washed with water, brine, and finally dried over anhydrous $\mathrm{Na}_{2} \mathrm{SO}_{4}$. It was concentrated in vacuo and the residue was chromatographed over silica gel to give the diol 6 as a yellow oil; Yield $7.5 \mathrm{~g}$ (55\%; but $88 \%$ after recovery of starting material); $R_{\mathrm{f}} 0.45$ (50\% EtOAc in petroleum ether); $[\alpha]_{\mathrm{D}}^{25}+24.8$ (c 1.0, $\mathrm{CHCl}_{3}$ ); IR (thin film) 3430 , 3040, $1450 \mathrm{~cm}^{-1} ;{ }^{1} \mathrm{H}$ NMR (300 MHz, $\left.\mathrm{CDCl}_{3}\right) \delta 1.36(\mathrm{~s}, 3 \mathrm{H}), 1.47$ (s, 3H), 2.05 (bs, 1H, -OH); $2.93(\mathrm{~s}, 1 \mathrm{H},-\mathrm{OH}) ; 3.63(\mathrm{~m}, 4 \mathrm{H}), 3.94(\mathrm{~m}, 2 \mathrm{H}), 4.07(\mathrm{~m}, 1 \mathrm{H}), 4.31(\mathrm{q}, J=6.6 \mathrm{~Hz}, 1 \mathrm{H}), 4.64$ $(\mathrm{ABd}, J=11.4 \mathrm{~Hz}, 2 \mathrm{H}), 4.77(\mathrm{ABd}, J=11.4 \mathrm{~Hz}, 2 \mathrm{H}) ; 7.33(\mathrm{~m}, 10 \mathrm{H})$; MS (FAB): $403(\mathrm{M}+1)$. Anal. calcd. for $\mathrm{C}_{23} \mathrm{H}_{30} \mathrm{O}_{6}$ : C, 68.64; H, 7.51. Found: C, 68.70; H, 7.60.

2,3-Bis-benzyloxy-3-(2,2-dimethyl-[1,3]dioxolan-4-yl)-propan-1-ol (7). The crude aldehyde obtained by oxidative cleavage of the diol 6 (1 g, $2.48 \mathrm{mmol})$ was taken in dry EtOH and cooled to $0{ }^{\circ} \mathrm{C}$. To this cooled solution, $\mathrm{NaBH}_{4}(142 \mathrm{mg}, 3.74 \mathrm{mmol})$ was added and stirred for $1 \mathrm{~h}$. The reaction mixture was quenched by an addition of saturated $\mathrm{NH}_{4} \mathrm{Cl}$ and $\mathrm{EtOH}$ was removed in vacuo. The aqueous layer was extracted with EtOAc, the combined organic layer was washed with water and brine. The organic layer was finally dried over $\mathrm{Na}_{2} \mathrm{SO}_{4}$, concentrated in vacuo and the residue was chromatographed over silica gel to give an alcohol 7 as a colorless oil; Yield $920 \mathrm{mg}$ (99\%), $R_{\mathrm{f}} 0.28$ (20\% EtOAc in petroleum ether); ${ }^{1} \mathrm{H} \mathrm{NMR}\left(400 \mathrm{MHz}, \mathrm{CDCl}_{3}\right) \delta 1.35$ (s, $3 \mathrm{H}), 1.44(\mathrm{~s}, 3 \mathrm{H}), 3.59-3.68(\mathrm{~m}, 2 \mathrm{H}), 3.75(\mathrm{dd}, J=11.1,5.1 \mathrm{~Hz}, 1 \mathrm{H}), 3.82(\mathrm{t}, J=4.6 \mathrm{~Hz}, 1 \mathrm{H})$, $3.97(\mathrm{~m}, 1 \mathrm{H}), 4.05(\mathrm{dd}, J=8.3,6.4 \mathrm{~Hz}, 1 \mathrm{H}), 4.24(\mathrm{~m}, 1 \mathrm{H}), 4.63(\mathrm{~s}, 2 \mathrm{H}), 4.73(\mathrm{~m}, 2 \mathrm{H}), 7.31(\mathrm{~m}$, $10 \mathrm{H}) ;{ }^{13} \mathrm{C}$ NMR $\left(100 \mathrm{MHz}, \mathrm{CDCl}_{3}\right) \delta 25.4,26.8,61.8,66.5,73.0,75.0,76.7,79.6,80.3,108.9$, 128.2, 128.25, 128.3, 128.5, 128.8, 138.3; MS (FAB): $373(\mathrm{M}+1)$; Anal. Calcd. for $\mathrm{C}_{22} \mathrm{H}_{28} \mathrm{O}_{5}$ : C, 70.94; H, 7.58. Found: C, 70.88; H, 7.54.

4-(1,2-Bis-benzyloxy-propyl)-2,2-dimethyl-[1,3]dioxolane (8). A solution of the alcohol 7 ( $656 \mathrm{mg}, 1.76 \mathrm{mmol})$ and $\mathrm{Et}_{3} \mathrm{~N}(730 \mu \mathrm{l}, 5.2 \mathrm{mmol})$ in $\mathrm{CH}_{2} \mathrm{Cl}_{2}$ was treated with tosyl chloride (369mg, $1.93 \mathrm{mmol}$ ) and stirred for $12 \mathrm{~h}$ at $\mathrm{rt}$. The reaction mixture was diluted with large excess of ether and organic layer was washed with water and brine. The organic layer was finally dried over $\mathrm{Na}_{2} \mathrm{SO}_{4}$ and concentrated in vacuo. The crude tosylated product was then subjected to reduction as such. The tosylate solution in dry DMSO $(10 \mathrm{ml})$ was treated with $\mathrm{NaBH}_{4}(665 \mathrm{mg}, 17.6 \mathrm{mmol})$ for $7 \mathrm{~min}$ at $160{ }^{\circ} \mathrm{C}$. The flask was cooled, and the reaction mixture was quenched by careful addition of water and extracted with ether. The combined organic layers were washed with water, brine and finally dried over $\mathrm{Na}_{2} \mathrm{SO}_{4}$. It was concentrated and the residue was chromatographed over silica gel to give 8 as a colorless oil; Yield $628 \mathrm{mg}(73 \%) ; R_{\mathrm{f}}$ 0.71 (10\% EtOAc in petroleum ether); IR (thin film): $3031,2976,1495 \mathrm{~cm}^{-1} ;{ }^{1} \mathrm{H}$ NMR (400 $\left.\mathrm{MHz}, \mathrm{CDCl}_{3}\right) \delta 1.17(\mathrm{~d}, J=6.6 \mathrm{~Hz}, 3 \mathrm{H}), 1.35(\mathrm{~s}, 3 \mathrm{H}), 1.43(\mathrm{~s}, 3 \mathrm{H}), 3.61-3.70(\mathrm{~m}, 2 \mathrm{H}), 4.00$ (d, $J=7.1 \mathrm{~Hz}, 2 \mathrm{H}), 4.26(\mathrm{~m}, 1 \mathrm{H}), 4.44(\mathrm{ABd}, J=11.7 \mathrm{~Hz}, 1 \mathrm{H}), 4.58(\mathrm{ABd}, J=11.7 \mathrm{~Hz}, 1 \mathrm{H}), 4.67$ $(\mathrm{ABd}, J=11.5 \mathrm{~Hz}, 1 \mathrm{H}), 4.78(\mathrm{ABd}, J=11.5 \mathrm{~Hz}, 1 \mathrm{H}), 7.30(\mathrm{~m}, 10 \mathrm{H}) ;{ }^{13} \mathrm{C} \mathrm{NMR}(100 \mathrm{MHz}$, 
$\left.\mathrm{CDCl}_{3}\right) \delta 15.9,25.1,26.5,65.6,71.2,74.7,74.9,76.8,81.1,108.0,127.5,127.6,127.8,128.0$, 128.2, 128.3, 138.41, 138.46; MS (FAB): $357(\mathrm{M}+1)$; Anal. Calcd. for $\mathrm{C}_{22} \mathrm{H}_{28} \mathrm{O}_{4}$ : C, 74.13; $\mathrm{H}$, 7.92. Found: C,

$74.08 ; \mathrm{H}, 7.87$.

3,4-Bis-benzyloxy-pentane-1,2-diol (9). $600 \mathrm{mg}$ of the acetonide 8 provided $458 \mathrm{mg}$ (yield $86 \%)$ of the diol 9 as per the general procedure; $R_{\mathrm{f}} 0.40\left(40 \%\right.$ EtOAc in petroleum ether); $[\alpha]^{25}{ }_{\mathrm{D}}$ - 2.4 (c 0.5, $\mathrm{CHCl}_{3}$ ); IR (thin film): 3394, 3031, 1494, $1495 \mathrm{~cm}^{-1} ;{ }^{1} \mathrm{H} \mathrm{NMR}\left(400 \mathrm{MHz}, \mathrm{CDCl}_{3}\right) \delta$ $1.32(\mathrm{~d}, J=6.3 \mathrm{~Hz}, 3 \mathrm{H}) ; 3.36(\mathrm{bs},-\mathrm{OH}, 2 \mathrm{H}) ; 3.63(\mathrm{dd}, J=7.8,4.2 \mathrm{~Hz}, 1 \mathrm{H}) ; 3.75(\mathrm{dABq}, J=11.5$, $4.6,3.2 \mathrm{~Hz}, 2 \mathrm{H}) ; 3.90(\mathrm{~m}, 2 \mathrm{H}) ; 4.50(\mathrm{~d}, J=11.7 \mathrm{~Hz}, 1 \mathrm{H}), 4.63(\mathrm{~m}, 3 \mathrm{H}), 7.32(\mathrm{~m}, 10 \mathrm{H}) .{ }^{13} \mathrm{C} \mathrm{NMR}$ $\left(100 \mathrm{MHz}, \mathrm{CDCl}_{3}\right) \delta 14.4,63.2,70.91,70.96,73.3,74.7,78.4,127.6,127.8,128.2,128.23$, 137.5, 137.8. MS (FAB): $317(\mathrm{M}+1)$; Anal. Calcd. for $\mathrm{C}_{19} \mathrm{H}_{24} \mathrm{O}_{4}$ : C, 72.13; H, 7.65. Found: $\mathrm{C}$, $72.07 ; \mathrm{H}, 7.56$.

5-(1-Hydroxy-ethyl)-dihydro-furan-2-one (1a). $400 \mathrm{mg}$ of the $\alpha, \beta$-unsaturated ester 10 gave $118 \mathrm{mg}$ (95\% yield) of $1 \mathrm{a}$ as a colorless oil; $R_{\mathrm{f}} 0.32$ (50\% EtOAc in petroleum ether); $[\alpha]^{25}{ }_{\mathrm{D}}^{-}$ 48.6 (c 0.9, $\mathrm{CHCl}_{3}$ ); IR (thin film) 3459, 2982, $1771 \mathrm{~cm}^{-1} ;{ }^{1} \mathrm{H} \mathrm{NMR}\left(400 \mathrm{MHz}, \mathrm{CDCl}_{3}\right) \delta 1.26$ (d, $J=6.6 \mathrm{~Hz}, 3 \mathrm{H}), 2.00-2.10(\mathrm{~m}, 1 \mathrm{H}), 2.22-2.30(\mathrm{~m}, 1 \mathrm{H}), 2.50-2.66(\mathrm{~m}, 2 \mathrm{H}), 3.79(\mathrm{~m}, 1 \mathrm{H})$, $3.35(\mathrm{dt}, J=7.3,5.4 \mathrm{~Hz}, 1 \mathrm{H}) .{ }^{13} \mathrm{C} \mathrm{NMR}\left(100 \mathrm{MHz}, \mathrm{CDCl}_{3}\right) \delta 18.5,24.0,28.7,69.9,84.2,177.1$. MS (FAB): $131(\mathrm{M}+1)$. Anal. Calcd. for $\mathrm{C}_{6} \mathrm{H}_{10} \mathrm{O}_{3}: \mathrm{C}, 55.37 ; \mathrm{H}, 7.74$. Found: $\mathrm{C}, 55.40 ; \mathrm{H}, 7.73$.

4-(1,2-Bis-benzyloxy-hex-3-enyl)-2,2-dimethyl-[1,3]dioxolane (11b). $1 \mathrm{~g}$ of the diol 6 provided $758 \mathrm{mg}$ (yield $77 \%$ for two steps) of the olefin $11 \mathrm{~b}$ as a colorless oil; $R_{\mathrm{f}} 0.49(10 \%$ EtOAc in petroleum ether); $[\alpha]^{25}-11.1\left(\mathrm{c} 0.9, \mathrm{CHCl}_{3}\right)$; IR (thin film): 3029, 2930, 1495, $1455 \mathrm{~cm}^{-1} ;{ }^{1} \mathrm{H}$ NMR $\left(400 \mathrm{MHz}, \mathrm{CDCl}_{3}\right) \delta 0.89(\mathrm{t}, J=7.6 \mathrm{~Hz}, 3 \mathrm{H}) ; 1.29(\mathrm{~s}, 3 \mathrm{H}) ; 1.35(\mathrm{~s}, 3 \mathrm{H}) ; 1.89-1.98(\mathrm{~m}$, $2 \mathrm{H}) ; 3.67(\mathrm{dd}, J=4.2,3.9 \mathrm{~Hz}, 1 \mathrm{H}) ; 3.93(\mathrm{~m}, 2 \mathrm{H}) ; 4.18(\mathrm{~m}, 2 \mathrm{H}) ; 4.26(\mathrm{~d}, J=12 \mathrm{~Hz}, 1 \mathrm{H}) ; 4.54(\mathrm{~d}, J$ $=12 \mathrm{~Hz}, 1 \mathrm{H}) ; 4.68(\mathrm{~m}, 2 \mathrm{H}) ; 5.37(\mathrm{~m}, 1 \mathrm{H}) ; 5.59,(\mathrm{td}, J=11,7.1 \mathrm{~Hz}, 1 \mathrm{H}) ; 7.25(\mathrm{~m}, 10 \mathrm{H}) .{ }^{13} \mathrm{C} \mathrm{NMR}$ $\left(100 \mathrm{MHz}, \mathrm{CDCl}_{3}\right) \delta 14.1,21.1,25.3,26.4,65.4,70.0,74.3,75.1,76.6,81.5,108.1,126.5$, 127.38, 127.44, 127.6, 127.9, 128.1, 128.3, 136.5, 138.3, 138.5. MS (FAB): 397 (M+1). Anal. Calcd. for $\mathrm{C}_{25} \mathrm{H}_{32} \mathrm{O}_{4}$ : C, 75.73; H, 8.13. Found: C, 75.65; H, 8.09.

4-(1,2-Bis-benzyloxy-hept-3-enyl)-2,2-dimethyl-[1,3]dioxolane (11c). $1 \mathrm{~g}$ of the diol 6 provided $780 \mathrm{mg}$ (yield $79 \%$ for two steps) of the olefin 11c as a colorless oil; $R_{\mathrm{f}} 0.55(10 \%$ EtOAc in petroleum ether); $[\alpha]^{25}-7.74$ (c 0.9, $\mathrm{CHCl}_{3}$ ); IR (thin film): 3029, 2958, 1495 , $1455 \mathrm{~cm}^{-1} ;{ }^{1} \mathrm{H}$ NMR $\left(400 \mathrm{MHz}, \mathrm{CDCl}_{3}\right) \delta 0.84(\mathrm{t}, J=6.4 \mathrm{~Hz}, 3 \mathrm{H}), 1.29(\mathrm{~s}, 3 \mathrm{H}), 1.33(\mathrm{~m}, 2 \mathrm{H})$, $1.35(\mathrm{~s}, 3 \mathrm{H}), 1.93(\mathrm{~m}, 2 \mathrm{H}), 3.67(\mathrm{t}, J=3.9 \mathrm{~Hz}, 1 \mathrm{H}), 3.92(\mathrm{~m}, 1 \mathrm{H}), 4.18(\mathrm{~m}, 1 \mathrm{H}), 4.27(\mathrm{~d}, J=$ $12 \mathrm{~Hz}, 1 \mathrm{H}), 4.54(\mathrm{~d}, J=12 \mathrm{~Hz}, 1 \mathrm{H}), 4.68(\mathrm{~m}, 2 \mathrm{H}), 5.42(\mathrm{~m}, 1 \mathrm{H}), 5.61(\mathrm{td}, J=11.6,11.2 \mathrm{~Hz}, 1 \mathrm{H})$, $7.25(\mathrm{~m}, 10 \mathrm{H}) .{ }^{13} \mathrm{C} \mathrm{NMR}\left(100 \mathrm{MHz}, \mathrm{CDCl}_{3}\right) \delta 13.8,22.7,25.3,26.4,29.8,65.4,70.1,74.4,75.1$, 76.7, 81.5, 108.1, 127.3, 127.4, 127.47, 127.8, 127.9, 128.14, 128.16, 134.8, 138.4, 138.5. Anal. Calcd. for $\mathrm{C}_{26} \mathrm{H}_{32} \mathrm{O}_{4}$ : C, 76.06; H, 8.35. Found: C, 76.00; H, 8.32.

4-(1,2-Bis-benzyloxy-tetradec-3-enyl)-2,2-dimethyl-[1,3]dioxolane (11d). $1 \mathrm{~g}$ of the diol 6 provided $884 \mathrm{mg}$ (yield $70 \%$ for two steps) of the olefin 11d as a colorless oil; $R_{\mathrm{f}} 0.65(10 \%$ EtOAc in petroleum ether); $[\alpha]^{25}-14.1$ (c $\left.1.8, \mathrm{CHCl}_{3}\right)$; IR (thin film): 3029, 2926, 1495. $1456 \mathrm{~cm}^{-1} ;{ }^{1} \mathrm{H}$ NMR $\left(400 \mathrm{MHz}, \mathrm{CDCl}_{3}\right): \delta 0.83(\mathrm{t}, J=6.6 \mathrm{~Hz}, 3 \mathrm{H}), 1.20(\mathrm{bs}, 16 \mathrm{H}), 1.29(\mathrm{~s}, 3 \mathrm{H})$, 
$1.35(\mathrm{~s}, 3 \mathrm{H}), 1.91(\mathrm{~m}, 2 \mathrm{H}), 3.67(\mathrm{dd}, J=4.2,3.9 \mathrm{~Hz}, 1 \mathrm{H}), 3.92(\mathrm{~m}, 2 \mathrm{H}), 4.19(\mathrm{~m}, 2 \mathrm{H}), 4.27(\mathrm{~d}, J=$ $12 \mathrm{~Hz}, 1 \mathrm{H}), 4.55(\mathrm{~d}, J=12 \mathrm{~Hz}, 1 \mathrm{H}), 4.68(\mathrm{~m}, 2 \mathrm{H}), 7.25(\mathrm{~m}, 10 \mathrm{H}), 5.40(\mathrm{dd}, J=11.2,9.5 \mathrm{~Hz}, 1 \mathrm{H})$, $5.60(\mathrm{td}, J=11.2,7.3 \mathrm{~Hz}, 1 \mathrm{H}) ;{ }^{13} \mathrm{C} \mathrm{NMR}\left(100 \mathrm{MHz}, \mathrm{CDCl}_{3}\right) \delta 22.7,25.3,26.5,27.9,29.3,29.4$, 29.5, 29.6, 31.9, 65.5, 70.1, 74.4, 75.2, 76.7, 81.5, 108.1, 127.1, 127.4, 127.5, 127.8, 128.0, 128.2, 128.21, 135.2, 138.4, 138.5; MS (FAB): 509 (M+1). Anal. Calcd. for $\mathrm{C}_{33} \mathrm{H}_{48} \mathrm{O}_{4}: \mathrm{C}, 77.91$; H, 9.51. Found: C, 77.86; H, 9.42.

4-(1,2-Bis-benzyloxy-4-phenyl-but-3-enyl)-2,2-dimethyl-[1,3]dioxolane (11e). $1 \mathrm{~g}$ of the diol 6 provided $950 \mathrm{mg}$ (86\% for two steps) of 11e as a colorless oil; $R_{\mathrm{f}} 0.55$ (10\% EtOAc in petroleum ether); $[\alpha]^{25}$ D $-54.2\left(\mathrm{c} 1.5, \mathrm{CHCl}_{3}\right)$; IR (thin film): $3029,2985,1494,1453 \mathrm{~cm}^{-1} ;{ }^{1} \mathrm{H}$ NMR (400 MHz, $\left.\mathrm{CDCl}_{3}\right) \delta 1.32(\mathrm{~s}, 0.9 \mathrm{H}), 1.34(\mathrm{~s}, 2.1 \mathrm{H}), 1.40(\mathrm{~s}, 0.9 \mathrm{H}), 1.42(\mathrm{~s}, 2.1 \mathrm{H}), 3.81-$ $4.80(\mathrm{~m}, 9 \mathrm{H}), 5.80(\mathrm{dd}, J=11.5,9.9 \mathrm{~Hz}, 0.29 \mathrm{H}), 6.22(\mathrm{dd}, J=16.1,7.8 \mathrm{~Hz}, 0.71 \mathrm{H}), 6.58(\mathrm{~d}, J=$ $16.1 \mathrm{~Hz}, 0.71 \mathrm{H}), 6.75(\mathrm{~d}, J=11.5 \mathrm{~Hz}, 0.29 \mathrm{H}), 7.16-7.38(\mathrm{~m}, 15 \mathrm{H}) ;{ }^{13} \mathrm{C} \mathrm{NMR}(100 \mathrm{MHz}$, $\left.\mathrm{CDCl}_{3}\right) \delta 25.1,25.3,26.5,65.5,65.8,70.3,70.7,74.0,75.07,75.1,76.6,80.2,81.5,81.8,108.2$, $126.5,126.8,127.2,127.4,127.5,127.6,127.9,128.1,128.24,128.29,128.6,130.1,133.1$, 133.5, 136.3, 136.4, 137.9, 138.1, 138.2, 138.3; MS (FAB): $445(\mathrm{M}+1)$. Anal. Calcd. for $\mathrm{C}_{29} \mathrm{H}_{32} \mathrm{O}_{4}$ : C, 78.35; H, 7.26. Found: C, 78.26; H, 7.18.

3,4-Bis-benzyloxy-oct-5-ene-1,2-diol (12b). $740 \mathrm{mg}$ of the acetonide 11b provided $631 \mathrm{mg}$ (yield $95 \%$ ) of the diol $\mathbf{1 2 b}$ as a viscous liquid; $R_{\mathrm{f}} 0.50$ (40\% EtOAc in petroleum ether); $[\alpha]^{25}{ }_{\mathrm{D}}$ - 2.8 (c 1.4, $\mathrm{CHCl}_{3}$ ); IR (thin film): 3461, 2928, 1495, $1494 \mathrm{~cm}^{-1} ;{ }^{1} \mathrm{H} \mathrm{NMR}\left(400 \mathrm{MHz}, \mathrm{CDCl}_{3}\right) \delta$ $0.98(\mathrm{t}, J=7.6 \mathrm{~Hz}, 3 \mathrm{H}), 2.04(\mathrm{~m}, 2 \mathrm{H}), 3.66(\mathrm{~m}, 3 \mathrm{H}), 3.84,(\mathrm{~m}, 1 \mathrm{H}), 4.33(\mathrm{~d}, J=12 \mathrm{~Hz}, 1 \mathrm{H}), 4.44$ $(\mathrm{dd}, J=9.8,4.9 \mathrm{~Hz}, 1 \mathrm{H}), 4.58(\mathrm{~d}, J=11.2 \mathrm{~Hz}, 1 \mathrm{H}), 4.66(\mathrm{~d}, J=12 \mathrm{~Hz}, 1 \mathrm{H}), 4.72(\mathrm{~d}, J=11.2 \mathrm{~Hz}$, $1 \mathrm{H}), 5.49(\mathrm{~m}, 1 \mathrm{H}), 5.77(\mathrm{td}, J=11.2,7.3 \mathrm{~Hz}, 1 \mathrm{H}), 7.30(\mathrm{~m}, 10 \mathrm{H}) .{ }^{13} \mathrm{C} \mathrm{NMR}\left(100 \mathrm{MHz}, \mathrm{CDCl}_{3}\right) \delta$ 14.1, 21.3, 63.4, 70.1, 71.1, 74.36, 74.43, 80.8, 124.9, 127.8, 127.9, 128.1, 128.4, 128.5, 137.79, 137.84, 138.2. MS (FAB): $357(\mathrm{M}+1)$. Anal. Calcd. for $\mathrm{C}_{22} \mathrm{H}_{28} \mathrm{O}_{4}: \mathrm{C}, 74.13 ; \mathrm{H}, 7.92$. Found: $\mathrm{C}$, 74.06, H, 7.88 .

3,4-Bis-benzyloxy-non-5-ene-1,2-diol (12c). $780 \mathrm{mg}$ of the acetonide 11c provided $675 \mathrm{mg}$ (yield $96 \%$ ) of the diol 12c; $R_{\mathrm{f}} 0.51$ in (40\% EtOAc in petroleum ether); $[\alpha]_{\mathrm{D}}^{25}-3.9$ (c 0.9 , $\left.\mathrm{CHCl}_{3}\right)$; IR (thin film): 3442, 2930, 1495, $1454 \mathrm{~cm}^{-1} ;{ }^{1} \mathrm{H} \mathrm{NMR}\left(400 \mathrm{MHz}, \mathrm{CDCl}_{3}\right) \delta 0.88(\mathrm{t}, J=$ $7.3 \mathrm{~Hz}, 3 \mathrm{H}), 1.36(\mathrm{~m}, 2 \mathrm{H}), 1.98(\mathrm{~m}, 2 \mathrm{H}), 2.61(\mathrm{bs}, 1 \mathrm{H}), 3.37(\mathrm{bs}, 1 \mathrm{H}), 3.64(\mathrm{~m}, 3 \mathrm{H}), 3.83(\mathrm{~m}, 1 \mathrm{H})$, $4.32(\mathrm{~d}, J=12 \mathrm{~Hz}, 1 \mathrm{H}), 4.43(\mathrm{dd}, J=9.5,4.1 \mathrm{~Hz}, 1 \mathrm{H}), 4.60(\mathrm{~m}, 1 \mathrm{H}), 4.69(\mathrm{~d}, J=11.6 \mathrm{~Hz}, 1 \mathrm{H})$, $5.52(\mathrm{dd}, J=11,9.5 \mathrm{~Hz}, 1 \mathrm{H}), 5.74(\mathrm{td}, J=11,7.6 \mathrm{~Hz}, 1 \mathrm{H}), 7.27(\mathrm{~m}, 10 \mathrm{H}) .{ }^{13} \mathrm{C} \mathrm{NMR}(100 \mathrm{MHz}$, $\left.\mathrm{CDCl}_{3}\right) \delta 13.7,22.6,29.8,63.2,69.9,71.1,74.2,74.3,80.9,125.8,127.6,127.64,127.69,127.9$, 128.2, 128.23, 136.1, 137.77, 137.82; Anal. Calcd. for $\mathrm{C}_{23} \mathrm{H}_{30} \mathrm{O}_{4}$ : C, 74.56; H, 8.16. Found: C, $74.50 ; \mathrm{H}, 8.12$.

3,4-Bis-benzyloxy-hexadec-5-ene-1,2-diol (12d). $865 \mathrm{mg}$ of the acetonide 11d provided $733 \mathrm{mg}$ (92\% yield) of the diol 12d as a viscous liquid; $R_{\mathrm{f}} 0.64$ (40\% EtOAc in petroleum ether); $[\alpha]^{25}-4.4$ (c 0.9, $\mathrm{CHCl}_{3}$ ); IR (thin film): 3441, 2925, 1495, $1455 \mathrm{~cm}^{-1} ;{ }^{1} \mathrm{H} \mathrm{NMR}(400 \mathrm{MHz}$, $\left.\mathrm{CDCl}_{3}\right) \delta 0.88(\mathrm{t}, J=6.6 \mathrm{~Hz}, 3 \mathrm{H}), 1.26(\mathrm{bs}, 16 \mathrm{H}), 2.00(\mathrm{~m}, 2 \mathrm{H}), 3.66(\mathrm{~m}, 3 \mathrm{H}), 3.83(\mathrm{~m}, 1 \mathrm{H}), 4.33$ $(\mathrm{d}, J=12 \mathrm{~Hz}, 1 \mathrm{H}), 4.44(\mathrm{dd}, J=9.8,4.9 \mathrm{~Hz}, 1 \mathrm{H}), 4.59(\mathrm{~d}, J=11.2 \mathrm{~Hz}, 1 \mathrm{H}), 4.63(\mathrm{~d}, J=12 \mathrm{~Hz}$, $1 \mathrm{H}), 4.72(\mathrm{~d}, J=11.2 \mathrm{~Hz}, 1 \mathrm{H}), 5.51(\mathrm{dd}, J=11,9.8 \mathrm{~Hz}, 1 \mathrm{H}), 5.77(\mathrm{td}, J=11.2,7.3 \mathrm{~Hz}, 1 \mathrm{H}), 7.30$ 
(m, 10H); ${ }^{13} \mathrm{C}$ NMR $\left(100 \mathrm{MHz}, \mathrm{CDCl}_{3}\right) \delta 22.7,28.1,29.3,29.4,29.5,29.6,31.9,63.4,70.1,71.2$, 74.4, 74.6, 80.9, 125.5, 127.8, 127.9, 127.92, 128.2, 128.4, 128.5, 136.9, 137.85, 137.89; MS (FAB): 469 (M+1); Anal. Calcd. for $\mathrm{C}_{30} \mathrm{H}_{44} \mathrm{O}_{4}$ : C, 76.88; H, 9.46. Found: C, 76.73; H, 9.31.

3,4-Bis-benzyloxy-6-phenyl-hex-5-ene-1,2-diol (12e). $930 \mathrm{mg}$ of the acetonide 11e provided $753 \mathrm{mg}$ ( $89 \%$ yield) of the diol 12e as a viscous liquid; $\mathrm{R}_{\mathrm{f}} 0.63$ (40\% EtOAc in petroleum ether); $[\alpha]^{25}-29.6$ (c 0.9, $\mathrm{CHCl}_{3}$ ); IR (thin film): $3434,3029,1494,1452 \mathrm{~cm}^{-1}$; ${ }^{1} \mathrm{H}$ NMR (400 MHz, $\left.\mathrm{CDCl}_{3}\right) \delta 2.60(\mathrm{bs}, 2 \mathrm{H},-\mathrm{OH}), 3.57-4.71(\mathrm{~m}, 9 \mathrm{H}), 5.88(\mathrm{dd}, J=12.0,10.0 \mathrm{~Hz}, 0.29 \mathrm{H}), 6.29(\mathrm{dd}$, $J=16.1,7.6 \mathrm{~Hz}, 0.71 \mathrm{H}), 6.63(\mathrm{~d}, J=16.1 \mathrm{~Hz}, 0.71 \mathrm{H}), 6.87(\mathrm{~d}, J=12.0 \mathrm{~Hz}, 0.29), 7.17-7.40$ $(\mathrm{m}, 15 \mathrm{H}) ;{ }^{13} \mathrm{C}$ NMR $\left(100 \mathrm{MHz}, \mathrm{CDCl}_{3}\right) \delta 63.3,63.4,70.1,70.7,71.2,73.5,74.08,74.13,80.1$, $80.5,125.5,126.6,127.3,127.8,127.86,126.87,127.9,128.0,128.09,128.13,128.14,128.28$, 128.31, 128.35, 128.39, 128.48, 128.5, 128.6, 134.2, 134.9, 136.1, 136.3, 137.4, 137.5, 137.8; MS (FAB): 405 (M+1); Anal. Calcd. for $\mathrm{C}_{26} \mathrm{H}_{28} \mathrm{O}_{4}$ : C, 77.20; H, 6.98. Found: C, 77.11; H, 6.87. 5-(1-Hydroxy-pentyl)-dihydro-furan-2-one (1b). $520 \mathrm{mg}$ of $\alpha, \beta$-unsaturated ester 13b gave $157 \mathrm{mg}$ ( $80 \%$ yield) of the lactone $\mathbf{1 b}$ as a viscous liquid; Rf 0.43 (40\% EtOAc in petroleum ether); $[\alpha]^{25}{ }_{\mathrm{D}}-35.0$ (c 0.7, $\mathrm{CHCl}_{3}$ ); IR (thin film) 3441. 2931, $1768 \mathrm{~cm}^{-1} ;{ }^{1} \mathrm{H}$ NMR $(400 \mathrm{MHz}$, $\left.\mathrm{CDCl}_{3}\right) \delta 0.92(\mathrm{t}, J=7.1 \mathrm{~Hz}, 3 \mathrm{H}), 1.26-1.58(\mathrm{~m}, 6 \mathrm{H}), 2.13(\mathrm{~m}, 1 \mathrm{H}), 2.25(\mathrm{~m}, 1 \mathrm{H}), 2.49-2.67$ $(\mathrm{m}, 2 \mathrm{H}), 3.57(\mathrm{~m}, 1 \mathrm{H}), 4.43(\mathrm{dt}, J=7.3,4.4 \mathrm{~Hz}, 1 \mathrm{H}) .{ }^{13} \mathrm{C} \mathrm{NMR}\left(100 \mathrm{MHz}, \mathrm{CDCl}_{3}\right) \delta 13.9,22.5$, 24.0, 27.6, 28.7, 32.6,73.6, 82.9, 177.2. MS (FAB): $173(\mathrm{M}+1)$; Anal. Calcd. for $\mathrm{C}_{9} \mathrm{H}_{16} \mathrm{O}_{3}: \mathrm{C}$, 62.77; H, 9.36. Found: C, 62.68; H, 9.37.

5-(1-Hydroxy-hexyl)-dihydro-furan-2-one (1c). $520 \mathrm{mg}$ of the $\alpha, \beta$-unsaturated ester gave $185 \mathrm{mg}$ (yield $90 \%$ ) of the lactone 1c as a viscous liquid (previously it was reported as low melting solid, mp $\left.42{ }^{\circ} \mathrm{C}\right){ }^{17} R_{\mathrm{f}} 0.43$ (50\% EtOAc in petroleum ether); $[\alpha]^{25}-35.9$ (c 1.9, $\left.\mathrm{CHCl}_{3}\right)\left\{\mathrm{lit}^{17}-33.1\right.$ (c 1.6, $\left.\left.\mathrm{CHCl}_{3}\right)\right\}$; IR (thin film) 3446, 2954, $1780 \mathrm{~cm}^{-1} ;{ }^{1} \mathrm{H}$ NMR $(400 \mathrm{MHz}$, $\left.\mathrm{CDCl}_{3}\right) \delta 0.90(\mathrm{t}, J=7.1 \mathrm{~Hz}, 3 \mathrm{H}), 1.26-1.39(\mathrm{~m}, 6 \mathrm{H}), 1.54(\mathrm{~m}, 2 \mathrm{H}), 2.13(\mathrm{~m}, 1 \mathrm{H}), 2.25(\mathrm{~m}, 1 \mathrm{H})$, $2.38(\mathrm{bs}, 1 \mathrm{H}), 2.59(\mathrm{~m}, 2 \mathrm{H}), 3.57(\mathrm{~m}, 1 \mathrm{H}), 4.43(\mathrm{dt}, J=7.3,5.4 \mathrm{~Hz}, 1 \mathrm{H}) ;{ }^{13} \mathrm{C} \mathrm{NMR}\left(\mathrm{CDCl}_{3}\right) \delta$ 13.9, 22.5, 23.9, 25.1, 28.6, 31.6, 32.8, 73.5, 82.9, 177.4 .

(-)-Muricatacin (1d). $581 \mathrm{mg}$ of the $\alpha, \beta$-unsaturated ester gave $276 \mathrm{mg}$ (yield $95 \%$ ) of (-)muricatacin $1 \mathrm{~d}$ as a white solid; $\mathrm{mp}: 65^{\circ} \mathrm{C}\left(\right.$ lit $\left.^{9 \mathrm{~d}} \mathrm{mp} 71{ }^{\circ} \mathrm{C}\right) ; R_{\mathrm{f}} 0.51(40 \%$ EtOAc in petroleum ether); $[\alpha]^{25}$ - 23.5 (c $\left.0.43, \mathrm{CHCl}_{3}\right)\left\{\mathrm{lit}^{8}[\alpha]^{25}-23.3\left(\mathrm{c} 1.8, \mathrm{CHCl}_{3}\right)\right\}$; IR $\left(\mathrm{CDCl}_{3}\right.$ solution) 3570, $1765 \mathrm{~cm}^{-1} ;{ }^{1} \mathrm{H}$ NMR $\left(400 \mathrm{MHz}, \mathrm{CDCl}_{3}\right) \delta 0.88(\mathrm{t}, J=6.6 \mathrm{~Hz}, 3 \mathrm{H}), 1.26(\mathrm{bs}, 22 \mathrm{H}), 1.99(\mathrm{bs}, 1 \mathrm{H})$, $2.13(\mathrm{~m}, 1 \mathrm{H}), 2.26(\mathrm{~m}, 1 \mathrm{H}), 2.57(\mathrm{~m}, 2 \mathrm{H}), 3.57(\mathrm{~m}, 1 \mathrm{H}), 4.42(\mathrm{dt}, J=7.3,4 \mathrm{~Hz}, 1 \mathrm{H}) ;{ }^{13} \mathrm{C}$ NMR $\left(100 \mathrm{MHz}, \mathrm{CDCl}_{3}\right) \delta 28.7,29.3,29.5,29.6,29.6,31.9,32.9,73.6,82.9,177.1$; MS (FAB): 285 $(\mathrm{M}+1)$.

5-(1-Hydroxy-3-phenyl-propyl)-dihydro-furan-2-one (1e). $525 \mathrm{mg}$ of the $\alpha, \beta$-unsaturated ester provided $185 \mathrm{mg}$ ( $81 \%$ yield) of the lactone $1 \mathrm{e} ; R_{\mathrm{f}} 0.37$ (40\% EtOAc in petroleum ether); $[\alpha]_{D}^{25}-2.38\left(\mathrm{c} 0.8, \mathrm{CHCl}_{3}\right.$ ); IR (thin film) $3434,1767 \mathrm{~cm}^{-1} ; 1 \mathrm{H} \mathrm{NMR}(400 \mathrm{MHz}, \mathrm{CDCl} 3) \delta 1.75$ - $1.94(\mathrm{~m}, 2 \mathrm{H}), 2.07(\mathrm{~m}, 1 \mathrm{H}), 2.19(\mathrm{~m}, 1 \mathrm{H}), 2.44-2.61(\mathrm{~m}, 2 \mathrm{H}), 2.70(\mathrm{~m}, 1 \mathrm{H}), 2.86(\mathrm{~m}, 1 \mathrm{H})$, $3.55(\mathrm{dt}, J=9.5,3.9 \mathrm{~Hz}, 1 \mathrm{H}), 4.40(\mathrm{td}, J=7.3,4.4 \mathrm{~Hz}, 1 \mathrm{H}), 7.26(\mathrm{~m}, 5 \mathrm{H}) ;{ }^{13} \mathrm{C} \mathrm{NMR}(100 \mathrm{MHz}$, $\left.\mathrm{CDCl}_{3}\right) \delta 23.8,28.5,31.5,34.4,72.5,83.1,125.9,128.4,141.3,177.5$; MS (FAB): M+1 221. Anal. Calcd. for $\mathrm{C}_{13} \mathrm{H}_{16} \mathrm{O}_{3}$ : C, 70.89; H, 7.32. Found: C, 70.83; H, 7.30. 
3-[5-(1-Benzyloxy-pentyl)-2,2-dimethyl-[1,3]dioxolan-4-yl]-acrylic acid ethyl ester 15. To the diol 14 (224 mg, $0.67 \mathrm{mmol})$ in $3 \mathrm{ml}$ dry $\mathrm{CH}_{2} \mathrm{Cl}_{2}, \mathrm{~Pb}(\mathrm{OAc})_{4}(350 \mathrm{mg}, 0.73 \mathrm{mmol})$ was added at $0{ }^{\circ} \mathrm{C}$ and the reaction mixture was stirred for $4 \mathrm{~h}$ and worked up as earlier. The crude aldehyde was then taken in $\mathrm{MeOH}$ and to it (ethoxycarbonylmethylene)triphenyphosphorane ( $255 \mathrm{mg}, 0.73 \mathrm{mmol}$ ) was added and stirred for $12 \mathrm{~h}$ at $\mathrm{rt}$. All the $\mathrm{MeOH}$ was removed in vacuo and the residue was chromatographed over silica gel to provide the $\alpha, \beta$-unsaturated ester 15 (211 $\mathrm{mg}, 85 \%$ yield for two steps); $R_{\mathrm{f}} 0.65$ (10\% EtOAc in petroleum ether); ${ }^{1} \mathrm{H} \mathrm{NMR}(400 \mathrm{MHz}$, $\left.\mathrm{CDCl}_{3}\right) \delta 0.78(\mathrm{t}, J=6.8 \mathrm{~Hz}, 2.3 \mathrm{H}), 0.82(\mathrm{t}, J=6.8 \mathrm{~Hz}, 0.7 \mathrm{H}), 1.19(\mathrm{t}, J=7.2 \mathrm{~Hz}, 2.3 \mathrm{H}), 1.21(\mathrm{t}$, $J=7.2 \mathrm{~Hz}, 0.7 \mathrm{H}), 1.24-1.33(\mathrm{~m}, 4 \mathrm{H}), 1.37(\mathrm{~s}, 3 \mathrm{H}), 1.38(\mathrm{~s}, 3 \mathrm{H}), 1.43-1.58(\mathrm{~m}, 2 \mathrm{H}), 3.45(\mathrm{~m}$, $1 \mathrm{H}), 3.81(\mathrm{~m}, 1 \mathrm{H}), 4.08(\mathrm{q}, J=7.1 \mathrm{~Hz}, 1.4 \mathrm{H}), 4.12(\mathrm{q}, J=7.1 \mathrm{~Hz}, 0.6 \mathrm{H}), 4.40(\mathrm{~m}, 0.3 \mathrm{H}), 4.54$ $(\mathrm{m}, 1.4 \mathrm{H}), 4.70(\mathrm{ABd}, J=11.5 \mathrm{~Hz}, 0.6 \mathrm{H}), 5.50(\mathrm{~m}, 0.7 \mathrm{H}), 5.90(\mathrm{~m}, 1 \mathrm{H}), 6.06(\mathrm{dd}, J=9.3,4.6$ $\mathrm{Hz}, 0.7 \mathrm{H}), 6.76(\mathrm{dd}, J=15.6,5.6 \mathrm{~Hz}, 0.3 \mathrm{H}), 7.28(\mathrm{~m}, 5 \mathrm{H}) ;{ }^{13} \mathrm{C} \mathrm{NMR}\left(100 \mathrm{MHz}, \mathrm{CDCl}_{3}\right) \delta 13.94$, $13.99,14.1,14.2,22.6,22.7,26.7,26.93,26.98,27.2,27.7,27.9,30.1,30.5,72.4,72.5,72.8$, 76.1, 77.2, 78.9, 81.8, 83.6, 109.8, 122.4, 123.3, 127.3, 127.7, 127.9, 128.1, 128.1, 128.2, 128.4, 138.2, 138.9, 144.7, 145.2, 165.3, 166.0. Anal. Calcd. for $\mathrm{C}_{22} \mathrm{H}_{32} \mathrm{O}_{5}$ : C,70.18; H, 8.57. Found: C, $70.14 ; \mathrm{H}, 8.48$.

5-(1,2-Dihydroxy-hexyl)-dihydro-furan-2-one (17). The $\alpha, \beta$-unsaturated ester 15 (196 mg, $0.52 \mathrm{mmol}$ ) was taken in distilled $\mathrm{MeCN}(3 \mathrm{ml})$ and to it cupric chloride dihydrate $(222 \mathrm{mg}$, $1.30 \mathrm{mmol}$ ) was added and stirred overnight at $\mathrm{rt}$. The reaction was then quenched by addition of saturated aqueous $\mathrm{NaHCO}_{3}$ solution and extracted with EtOAc. The combined organic layers were dried over anhydrous $\mathrm{Na}_{2} \mathrm{SO}_{4}$ and concentrated in vacuo. The residue was chromatographed over silica gel to give $\alpha, \beta$-unsaturated lactone. This was subjected to hydrogenation as earlier using Palladium on activated charcoal to give the $\mathbf{1 7}$ as white solid; Yield $46 \mathrm{mg}$ (70\% for two steps) as colorless white solid; $R_{\mathrm{f}} 0.17$ (40\% EtOAc in petroleum ether); $[\alpha]^{25}{ }_{\mathrm{D}}-39.0$ (c 0.51 in $\mathrm{CHCl}_{3}$ ); ${ }^{1} \mathrm{H} \mathrm{NMR}\left(400 \mathrm{MHz}, \mathrm{CDCl}_{3}\right) \delta 0.39$ (t, J=7.0 Hz, 3H), $0.72-1.05(\mathrm{~m}, 6 \mathrm{H}), 1.76(\mathrm{~m}, 2 \mathrm{H}), 1.99(\mathrm{~m}, 1 \mathrm{H}), 2.13(\mathrm{~m}, 1 \mathrm{H}), 2.91(\mathrm{~m}, 1 \mathrm{H}), 3.20(\mathrm{~m}, 1 \mathrm{H}), 4.10$ $(\mathrm{dt}, J=6.8,3.6 \mathrm{~Hz}, 1 \mathrm{H}) ;{ }^{13} \mathrm{C} \mathrm{NMR}\left(100 \mathrm{MHz}, \mathrm{CDCl}_{3}\right) \delta 13.9,22.6,24.0,27.7,28.3,33.3,71.7$, 75.1, 81.5, 177.4. Anal. Calcd. for $\mathrm{C}_{10} \mathrm{H}_{18} \mathrm{O}_{4}$ : C, 59.39; H, 8.97. Found: C, 59.31; H, 8.89.

\section{Acknowledgments}

V.K.S. thanks CSIR for a research grant. We also thank CSIR, New Delhi for a Senior Research Fellowship to K.L.C. 


\section{References}

1. Numata, A.; Hokimoto, K.; Takemura, T.; Katsuno, T.; Yamamoto, K. Chem. Pharm. Bull. 1984, 32, 2815.

2. Cave, A.; Chaboche, C.; Figadere, B.; Harmange, J. C.; Laurens, A.; Peyrat, J. F.; Pichon, M.; Szlosek, M.; Cotte-Lafitte, J.; Quero, A. M. Eur. J. Med. Chem. 1997, 32, 617.

3. (a) Muller, C. J.; Maggiora, L.; Kepner, R. E.; Webb, A. D. J. Agric. Food Chem. 1969, 17, 1373. (b) Muller, C. J.; Kepner, R. E.; Webb, A. D. Am. J. Enol. Viticult. 1973, 24, 5. (c) Schumacher, J. N.; Green, C. R.; Best, F. W.; Newell, M. P.; J. Agric. Food Chem. 1977, 25 , 310.

4. Wright, A. E.; Matthias, M.; Midland, S.; Munnecke, D. E.; Sims, J. J. Tetrahedron Lett. 1989, 30, 5699.

5. Grafe, U.; Reinhardt, G.; Schade, W.; Krebs, D.; Eritt, I.; Fleck, W. F.; Heinrich, E.; Radics, L. J. Antibiotics 1982, 35, 609.

6. (a) Matsumoto, T.; Ichihara, A.; Ito, N. Tetrahedron. 1969, 25, 5889. (b) Iwaki, S.; Marumo, S.; Saito, T.; Yamada, M.; Katagiri, K. J. Am. Chem. Soc. 1974, 96, 7842. (c) Pearson, W.H.; Hembre, E. J. J. Org. Chem. 1996, 61, 7217. (d) Ha, J. D.; Cha, J. K. J. Am. Chem. Soc. 1999, 121, 10012. (e) Avedissian, H.; Sinha, S. C.; Yazbak, A.; Sinha, A.; Neogi, P.; Sinha, S. C.; Keinan, E. J. Org. Chem. 2000, 65, 6035.

7. (a) Nishi, T.; Kataoka, M.; Morisawa, Y. Chem. Lett. 1989, 1193. (b) Gante, J.; Kahlenberg, H. Chem.-Ztg. 1991, 115, 215. (c) Chakraborty, T. K.; Gangakhedkar, K. K. Tetrahedron Lett. 1991, 32, 1897. (d) Harding, K. E.; Coleman, M. T.; Liu, L. T. ibid. 1991, 32, 3795. (e) Ghosh, A. K.; McKee, S. P.; Thompson, W. J. J. Org. Chem. 1991, 56, 6500. (f) Poss, M. A.; Reid, J. A. Tetrahedron Lett. 1992, 33, 1411. (g) Askin, D.; Wallace, M. A.; Vacca, J. P.; Reamer, R. A.; Volante, R. P.; Shinkai, I. J. Org. Chem. 1992, 57, 2771.

8. Rieser, M. J.; Kozlowski, J. F.; Wood, K. V.; McLaughlin, J. L. Tetrahedron Lett. 1991, 32, 1137.

9. For synthesis of muricatacin from optically active starting materials, see: (a) Figadere, B.; Harmange, J-C.; Laurens, A.; Cave, A. Tetrahedron Lett. 1991, 32, 7539. (b) Pelletier, C. G.; Saniere, M.; Charvet, I.; Merrer, Y. L.; Depezay, J.-C. Tetrahedron Lett. 1994, 35, 115. (c) Somfai, P.; J. Chem. Soc., Perkin Trans. I 1995, 817. (d) Saniere, M.; Charvet, I.; Merrer, Y. L.; Depezay, J.-C. Tetrahedron 1995, 51, 1653. (e) Yoon, S-H.; Moon, H.-S.; Hwang, S.K.; Choi, S. R.; Kang, S.-K. Bioorg. Med. Chem. 1998, 6, 1043.

10. For synthesis of muricatacin by kinetic resolution, see: Saiah, M.; Bessodes, M.; Antonakis, K. Tetrahedron Lett. 1993, 34, 1597.

11. For syntheses of muricatacin using enantioselective methods, see: (a) Wang, Z.-M.; Zhang, X.-L.; Sharpless, K. B.; Sinha, S. C.; Sinha, A.-B.; Keinan, E. Tetrahedron Lett. 1992, 33, 6407. (b) Marshall, J. A.; Welmaker, G. S. J. Org. Chem. 1994, 59, 4122. (c) van Aar, M. P. M.; Thijs, L.; Zwanenburg, B. Tetrahedron 1995, 51, 11223. (d) Solladie, G.; Hanquet, G.; Izzo, I.; Crumbie, R.; Tetrahedron Lett. 1999, 40, 3071. 
12. For a preliminary account of this work, see: Chandrasekhar, M.; Chandra, K. L.; Singh, V. K. Tetrahedron Lett. 2002, 43, 2773.

13. Chandrasekhar, M.; Raina, S.; Singh, V. K. Tetrahedron Lett. 2000, 41, 4969.

14. Raina, S.; Singh, V. K. Tetrahedron 1996, 52, 4479.

15. (a) Kierstead, R. W.; Faraone, A.; Mennona, F.; Mullin, J.; Guthrie, R. W.; Crowley, H.; Simko, B. J. Med. Chem. 1983, 26, 1561. (b) Jurczak, J.; Bauer, T.; Chimielewski, M. Carbohydr. Res. 1987, 164, 493. (c) Wiggins, L. J. Chem. Soc. 1946, 13.

16. Saravanan, P.; Chandrasekhar, M.; Anand, R. V.; Singh, V. K. Tetrahedron Lett. 1998, 39, 3091.

17. Mori, K.; Otsuka, T. Tetrahedron 1985, 41, 3253. 